\title{
COMMUNICATIONS
}

\section{EVOLUTION OF PLASTIC MATERIAL IN THE SURGERY OF RETINAL DETACHMENT*}

\author{
BY \\ PETER RYCROFT \\ London
}

DURING the last decade retinal detachment surgery has undergone greater alteration in practice and technique than any other branch of ophthalmic surgery. So swiftly have the changes and modifications been introduced that proper evaluation of them has become clouded by their multiplicity. It has, therefore, become desirable to summarize the recent advances in historical sequence. Moreover, it should be remembered that these materials and operations were introduced to improve the prognosis of cases which were hitherto untreatable in the first instance, and only now are their indications in straightforward cases being critically assessed.

The examination of current literature has been complicated by this issue, for results which appeared in many cases to be fair, were, in fact, good, when the material presented for trial was taken into account. An additional difficulty is the lack of an international standard by which to determine what constitutes a successful result. No one would dispute that the retina must be flat, but for how long must it remain so post-operatively? Some surgeons quote 3 months, whereas other feel that at least a year is necessary; the current figures are inconsistent and consequently without much value.

The foundations of retinal surgery laid down by Gonin (1929) remain the guiding principles of to-day (Gonin, 1930a, b, 1933; Amsler, 1956). As Gonin himself stated, much of the surgeon's work in retinal detachment is already accomplished before the patient arrives in the operating theatre; localization of all the retinal tears, assessment of the extent of detachment, quantity of sub-retinal fluid, the state of the vitreous, its traction or collapse-all these factors are taken into consideration before planning a surgical procedure to suit the individual case.

Retinal surgeons have seen three major new advances in the last 10 years:

(1) The development of the Schepens binocular indirect ophthalmoscope (Schepens, 1951), with the addition of scleral indentation. The Fison instrument used in Great Britain has the advantage of lightness and comfort when worn for periods of up to 4 hours. The Hamblin model has improved illumination so that the lamp filament is not projected on to the retina.

(2) The invention of photocoagulation by Prof. G. Meyer-Schwickerath (1954); this is a form of controlled cautery reaction, demanding the presence of chorioretinal pigmentation and close apposition to achieve successful cohesion. Smaller and more manoeuvrable instruments are undergoing extensive trials already, and 
the use of lasers in this field is merely a matter of time and successful modification. The light coagulator is most useful in conjunction with retinal surgery in lieu of diathermy to a buckle, or to touch up areas incompletely sealed after diathermy (Meyer-Schwickerath, 1960).

(3) The advent of plastics to shorten the globe. Two main groups are predominant:

(i) The Polythene Group.-These are derived from polythene, a thermoplastic obtained by polymerizing the gas ethylene. It does not easily take up moisture and deposits do not readily form on its surface. It softens at $85^{\circ} \mathrm{C}$., must be supported at $100^{\circ} \mathrm{C}$., and melts at $110^{\circ} \mathrm{C}$; it may occur as low density polythene, molecular weight $15,000-45,000$, or high density polythene with a molecular weight up of to $1,000,000$. The basic formula is shown in Fig. 1.

FIG. 1.-Polythene derivation.
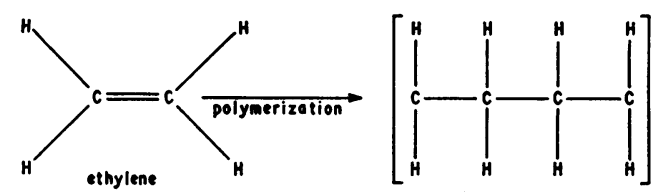

(ii) The Silicone Rubber Group.-This synthetic rubber, with improved working range from $-90^{\circ} \mathrm{C}$. to $+150^{\circ} \mathrm{C}$., is water repellent, and extremely resistant to heat, cold, or chemical attack. Silicone rubber consists of alternating silicone and oxygen atoms with variable organic atomic groups attached to the side chains (Fig. 2):

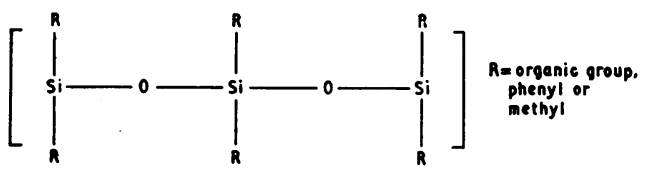

Fig. 2.-Silicone derivation.

The change from polythene tubes to silicone rubber rods has been made for the following reasons:

(a) Silicone rubber can be autoclaved indefinitely without losing its elasticity.

(b) It can be made in variable degrees of elasticity or fluidity.

(c) Sutures can be passed easily through solid silicone rubber and maintain fixation.

(d) A solid rod, or strap, has no lumen within which infection can arise, as has been reported with polythene tubes.

(e) The post-operative host tissue-reaction to a silicone rubber rod implant is markedly less than that to a polythene tube.

$(f)$ Silicone rubber can be moulded to almost any shape and retains that shape, whereas polythene tubes when curved tend to straighten out in time, a fact which accounts for the migration of inadequately fixed tubes some months or years post-operatively.

\section{Retinal Surgery before the Introduction of Plastics}

Gonin (1929) described his technique of perforating thermo- or galvano-cautery to the sclera over the retinal tears and drainage of sub-retinal fluid, which led to the 
successful replacement of the retina in 20 to 25 per cent. of cases. Modifications of this technique, using surface diathermy only and sometimes intravitreal air (Arruga, 1952) or saline, still produce good results in straightforward cases.

Lindner (1933) revived the full-thickness scleral resection, which is technically difficult and often dangerous, and may result in premature vitreous loss or severe choroidal haemorrhage. Shapland greatly improved this operation when he devised the lamellar scleral resection in 1949 (Shapland, 1951a, b, 1955, 1957, 1960a, b, 1961). This was also the year of the early experiments with the Custodis plombe and the first trials of photocoagulation (Meyer-Schwickerath, 1954, 1960).

Lamellar scleral resection, the first attempt at controlled surgery for retinal detachment, attained a success rate of 65 to 70 per cent. in all cases considered operable. Until the 1950s the choice of treatment lay between these two techniques, according to individual indications, but there were still many patients for whom neither was suitable who were considered to be desperate and untreatable cases:

(a) Total detachments with multiple peripheral retinal tears.

(b) Extensive detachments which failed to respond to posture because the vitreous was shrunken or was causing traction.

(c) Detachments in young persons with giant disinsertions of almost half the globe (fortunately these comprised only 1 per cent.).

(d) Total aphakic detachments, often with no holes visible, for whom scleral resection could be done only empirically.

(e) Those in whom primary procedures had failed.

Many failures were due to diathermy in which both the strength and the site of application was uncontrolled. The reaction of different individuals to the same strength of current varied considerably, and some surgeons demanded a strong reaction while others felt that it should be scarcely visible in the fundus. Strong diathermy reaction could coagulate vitreous strands, and their subsequent fibrosis and traction would cause a secondary tear either at the site of application or at a point immediately opposite to it on the other side of the globe.

The use of the indirect ophthalmoscope at operation now renders diathermy a controlled procedure, for both the strength and site are easily and accurately determined.

In lamellar scleral resections excessive sub-retinal fluid was always of some concern, for, in order to avoid a soft eye post-operatively and yet drain off all the fluid, the resection had to be lengthened or widened, both hazardous procedures, or an intravitreal injection of air or saline had to be given. The use of silicone rubber has largely overcome such difficulties; the ridge is deeper and more lasting, and can easily be made broader if necessary, and in this way the intra-ocular volume and pressure are maintained without intravitreal injection and its attendant risks.

The trend toward artificial implants began when Jess (1937) used a gauze tampon. His technique was to withdraw sub-retinal fluid into a syringe, to apply liberal diathermy to the sclera, and to leave a gauze tampon indenting the sclera for 14 days or until the intra-ocular pressure returned to normal. This tampon was held in place by sutures brought out through the conjunctiva. The operation was based on an earlier technique of Arruga, who injected blood into the supra-choroidal space. Strampelli (1954) implanted gelatine sponge into the suprachoroidal space. 
(1) Custodis Plombe Technique

The development of this technique first began in 1949 when Prof. E. Custodis (1951, 1953, 1956, 1959, 1962) implanted polyviol plastic stitched to the sclera, known in Great Britain as the Custodis plombe.

The essential preliminary is to localize all the retinal holes accurately by indentation with a cautery electrode. No scleral resection is done, but a true indentation or buckle. After surface diathermy over the site of the retinal tear, a tailored rod of Polyviol (Fig. 3) is firmly sutured to the sclera by two or three mattress sutures.
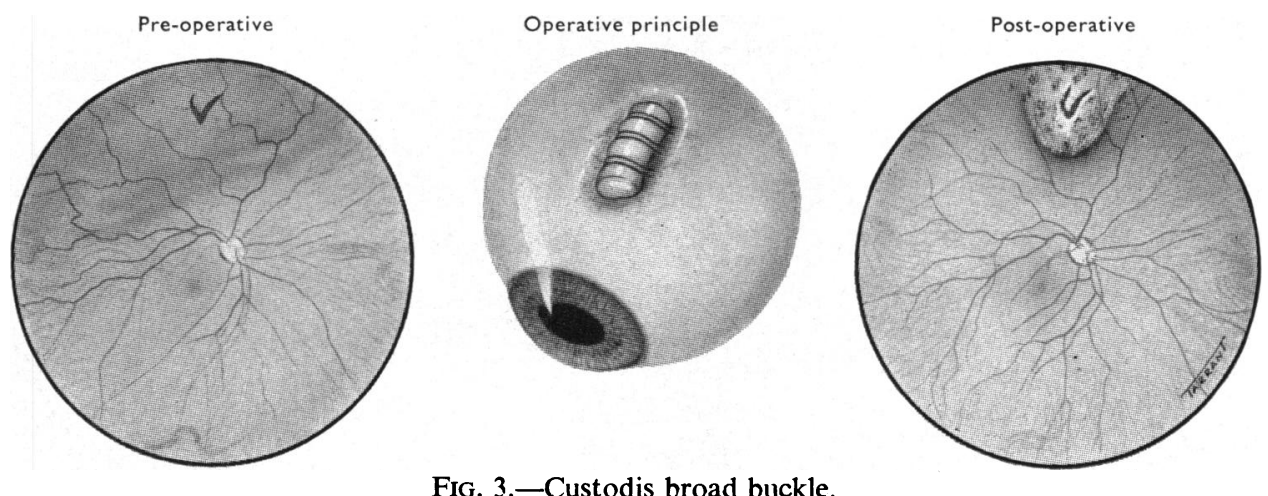

FIG. 3.-Custodis broad buckle.

More recently, Prof. Custodis (personal communication) has introduced silastic foam and silicone rubber. He finds that the latter is much tougher than Polyviol but causes less post-operative ocular reaction.

In order to seal the open tear, localization must be so accurate that no portion of the tear overlaps the shoulders of the buckle where leakage of sub-retinal fluid could seep beneath it and lift the retina off. Adequate diathermy reaction renders the seal permanent.

Until 1958 the sub-retinal fluid was not drained off but was allowed to absorb during the ensuing months. Since then it has been drained in some cases in which it was excessive, particularly in aphakia.

One implant is sewn to the sclera for every major retinal tear in the directioncircumferential or radial-necessary to cover it fully, and the plombes may be removed 2 or 3 months after healing. This method has the advantage of simplicity; there is no sectioning of extra-ocular muscles and no vitreous exposure. The depth of buckle is determined by scleral depression before tightening the sutures, and is a controlled procedure. Special care is taken to observe the pulsation of the central retinal artery, and to see that the intra-ocular pressure is normal at the end of the operation. Diamox or urea is given if necessary.

The patient is ambulant 1 or 2 days post-operatively in favourable cases; all are more quickly mobilized and are discharged sooner than those treated by the older techniques.

Before silicone rubber was used for the plombe, some difficulty in sterilization was experienced, and post-operative suppuration of the operation site was recorded. 
There was marked ocular reaction amounting to pain, chemosis, and choroidal exudation in some cases, while migration of the plombe and extrusion, with a sinus draining from the wound, were reported in others.

The most consistent disadvantage was pressure necrosis of the sclera beneath the plombe. Re-operation became hazardous, and secondary retinal tears were caused by too great an inward thrust of the buckle. Many of these complications will doubtless be reduced by the use of silicone rubber.

Of the early results, Rosengren and Törnquist (1958) report 76 per cent. of retinae replaced after 3 months, and Pau (1959a, b) replaced 369 out of 433 (85 per cent.). The commonest cause of failure among the complicated cases was peripheral retinal degeneration or multiple retinal tears.

\section{(2) SChepens TeChNiQues}

The concept of a plastic tube encircling the globe devised by Schepens (1951) was based on a new principle of volume reduction with increased area, and a more permanent ridge than a scleral fold. The reader is referred for details to the classical papers of Schepens and his associates (Okamura and Schepens, 1955; Schepens, Okamura, and Brockhurst, 1957, 1958; Brockhurst, Schepens, and Okamura, 1958; Okamura, Schepens, and Brockhurst, 1959; Schepens, Okamura, Brockhurst, and Regan, 1960; Schepens, 1960; Regan, Schepens, Okamura, Brockhurst, and McMeel, 1962).

The plastic first used was a polythene tube (P.E. 90) of diameter 1.27 to $2.08 \mathrm{~mm}$., with a braided silk suture within the lumen.

Scleral buckling was achieved by a tube encircling the globe in the region of the equator, positioning the retinal tears anterior to the buckle. When the suture was tightened and the volume of vitreous space reduced, an "hour-glass" constriction of the eye pressed the retina against the ridge by simultaneous release of sub-retinal fluid (Fig. 4).
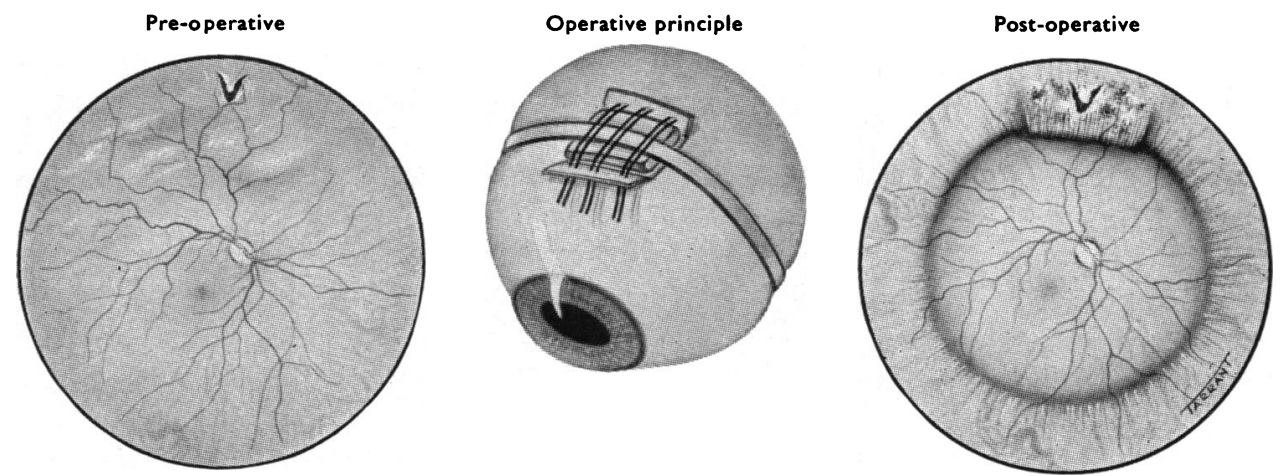

Fig. 4.-Schepens broad ridge.

The use of the encircling tube was accompanied by cutting a lamellar scleral resection over the site of major retinal tears, excising a strip of sclera, applying diathermy to the bed of the resection, burying the tube within it, and closing the resection over the tube with mattress sutures. One nylon suture anchored the tube in each quadrant of the globe. To pass the tube and suture it necessitated the removal of 3 or 4 extraocular muscles. 
Such an operation greatly improved the prognosis of the desperate cases hitherto considered inoperable. Nevertheless, it was a major surgical procedure on what must be regarded as severely-diseased eyes, and its increasing success and widening indications are tributes to the courage of the originators.

This principle has received world-wide acceptance, and attempts are now directed to make it less traumatic.

Schepens also advocated the use of a polythene tube buried within a lamellar scleral hemi-section; scleral buckling without resection-similar to the Custodis plombe operation; and trapdoor-flap sclerectomies with small buried tubes to cover local holes or to widen the buckle to encompass larger ones.

Once the principle of encircling plastic tubes was accepted, the importance of the success of the initial operation became evident. Re-operation after polythene implants became a trial of surgical skill and patience. Ragged conjunctiva and vascularized fibrosis of the previous operation site obscured tissue planes and bound down the extra-ocular muscles. Often the sclera was soft and friable, and pressure necrosis beneath the polythene tube exposed bare choroid when it was removed. Although ingenious polythene sheets were devised to cover such deficiencies, premature loss of sub-retinal fluid occurred all too often.

Post-operatively, many of the eyes reacted intensely to the plastic implant. The natural tendency of polythene being to straighten itself, tubes inadequately fixed in scleral resections tended to migrate, and in some cases to extrude themselves. Discharging fistulae and intra-luminal infections were reported, and Lincoff (1960) noted granulomata over the site of suture of the ends of the tube.

Surgeons therefore sought a more pliable less irritant plastic with elastic qualities.

McGregor $(1954,1957)$ reported trials of silicone rubber in surgery. Schepens was the first to develop it for ophthalmic use in the United States, and described many shapes, sizes, and types of implant (Schepens, 1960):

(i) Straight bands-rectangular or grooved.

(ii) Grooved implants to bear a polythene tube.

(iii) Curved implants cut from a cup-shaped mould and hand-carved to the individual case.

Simultaneously, Shea (1960) reported his results using a solid encircling rod of silicone rubber.

Varieties of rods and bands have continued to be produced, as the new material has been exploited. Everett and Scharrer (1961) designed a rod with a central mersilene suture core, and a sleeve which could be glued over the site of junction. Unfortunately, the rod is thereby rendered inelastic, a major disadvantage in the author's experience.

Girard and McPherson (1961, 1962) evolved a new method of equatorial fullthickness scleral buckle using an encircling rod of silicone rubber. The rod is tied by a slice suture on the stretch after drainage of sub-retinal fluid. Light coagulation is applied to seal off the retinal holes on the anterior surface of the ridge. The patient is confined to bed for 2 days or so, and in uncomplicated cases may leave hospital in a week.

This procedure has the advantage of relative simplicity. No scleral or muscle resection with the possible sequel of post-operative diplopia is necessary, and variable 
response to diathermy is excluded. However, the principal disadvantages since reported include post-operative migration of the rod and glaucoma.

Author's Method.-The basic technique is that of Fison and Hudson, derived from the overlap sclerectomy of Vannas (1958), with a silicone rubber rod inlay.

A scleral resection is cut around half the globe behind the larger retinal holes. No sclera is removed. A posterior flap is raised and deepened, using a Tookes knife, parallel to the scleral plane and $\frac{1}{2}-\frac{2}{3}$ deep. Surface diathermy of $60 \mathrm{~m} . \mathrm{a}$. is applied for $6 \mathrm{sec}$. to the resection bed, the amount of individual reaction being controlled by observation with the indirect ophthalmoscope.

The rod is passed around the globe and anchored beneath mattress sutures in the two exposed quadrants, the ends being overlapped beneath the larger holes and sewn together on the stretch after the release of sub-retinal fluid. The latter is drained by cautery application to the bed of the resection and final catholysis puncture through the choroid. More than two sites of puncture are not usually necessary. Remote fluid is massaged towards the drainage holes with a squint hook. The control of ocular tension is facilitated by the direct suturing of the scleral flap over the buried rod (Fig. 5).
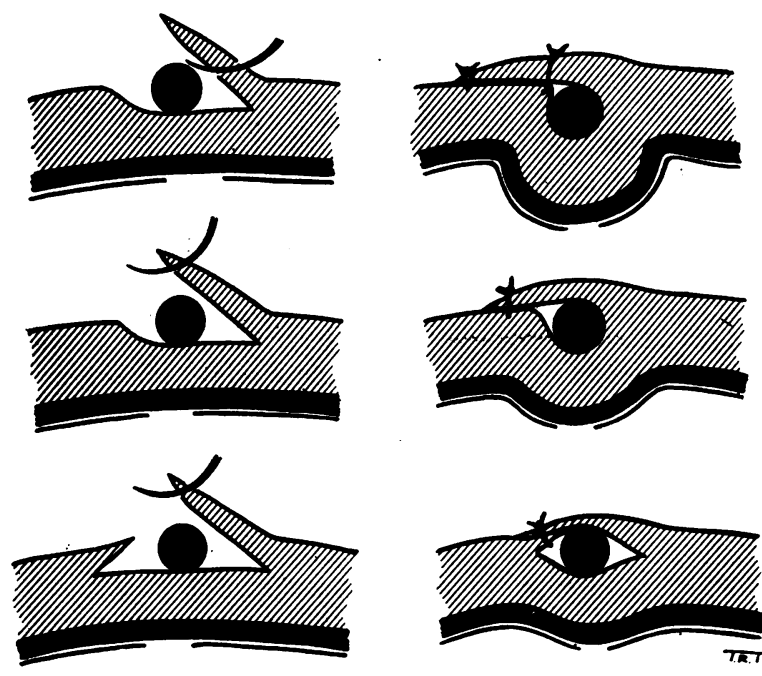

A. Potentially soft eye.

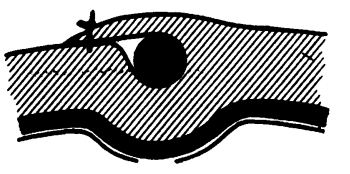

B. Average eye.

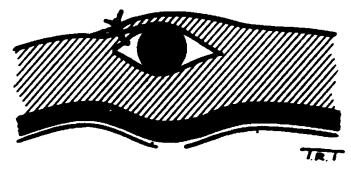

C. Firm eye.

Fig. 5.-Suturing the scleral overlap, after drainage of sub-retinal fluid, to maintain near normal intra-ocular pressure.

If the eye appears too soft, a deep bite is taken to the posterior edge of the flap-if firm, a more superficial bite of the anterior edge only is necessary, or an anterior flap can be mobilized without extending the sclerectomy.

Fortunately, severe total retinal detachments with multiple large tears are few, and the routine of hemi-section overlap sclerectomy and rod implant is usually sufficient. This procedure does not entail encircling the globe. Results so far have confirmed that silicone rubber is better tolerated, less irritating, and less apt to cause post-operative infection and migration than polythene.

Histologically, the initial response is one of acute inflammatory reaction with outpouring of polymorphs, exudate, and fibrin. As chronic inflammatory cells follow, there is little tendency for adhesion between host and rod, and eventually a fibrosed tube surrounds the rod, rendering it easily removable if required. 


\section{(3) Equatorial Cerclage}

The quest for simplicity continues and, at the time of writing, is best exemplified by equatorial cerclage, known in Great Britain as the Arruga String or Loop operation.

Arruga $(1957,1958 \mathrm{a})$ reported eleven cases treated by this method which he developed from that of Schepens (Fig. 6).
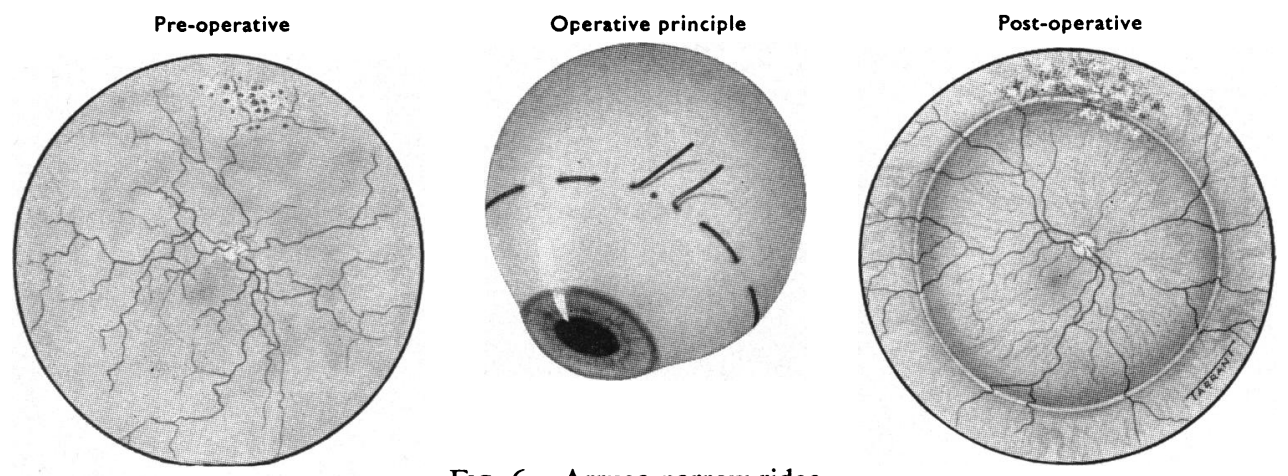

Fig. 6.-Arruga narrow ridge.

Fisher (personal communication) describes an excellent method of exposure for this technique:

"In Arruga's original article the conjunctiva and Tenon's capsule were incised parallel to the limbus. This method seems to have been followed by others in modifying the encircling materials used. It has been found, however, that this often results in inadequate exposure and subsequent tearing of the conjunctiva when attempting to place the "String" far back in posterior tears.

"Much more adequate exposure and minimal resuturing of the conjunctiva is achieved by a T-incision in each of the four quadrants between the recti. A suitable technique is as follows:

"An incision 4 to $6 \mathrm{~mm}$. long is made about $8 \mathrm{~mm}$. from the limbus, and circumferential to it. From the centre of this incision a radial extension is made backwards to the fornix, the conjunctiva and Tenon's capsule being incised separately. The globe is then fixed by placing squint hooks under each of the adjacent recti. If necessary, the Supramid encircling suture may then easily be placed well behind the equator of the globe. The suture should be fixed by passing the needle through the superficial scleral fibres for a length of about $3 \mathrm{~mm}$. This single area of suturing in each quadrant, even for an obliquely placed "String", is sufficient to fix it firmly in position.

"Drainage of the sub-retinal fluid is effected anterior to the string, initially by cautery puncture through the sclera, and finally by catholysis puncture through the choroid. The string is tied sufficiently firmly to produce approximately normal intra-ocular pressure, unless this would result in gross distortion of the globe, when Ringer's solution is injected intravitreally to replace the gross loss of intra-ocular fluid. Before the encircling string is finally tied, the sub-retinal drainage hole is closed by a small scleral suture. The conjunctiva in each quadrant is approximated by a single interrupted suture joining the corners of the T-incision. Later, a barrage of light coagulation to the ridge area may be necessary if the choroidal reaction appears insufficient."

The ridge so produced is a narrow one, and large retinal holes tend to straddle it and leak accordingly, especially if they lie well behind the equator. The scleral and choroidal reaction induced by the Supramid alone, without diathermy or light, is not always sufficient to make the retina permanently adhere to it in these cases. Nevertheless, this operation has definite advantages, the full extent of which are still being evaluated, and is particularly effective for:

(1) Aphakic detachments where the zonular tears are often minute.

(2) Total detachments in the elderly with multiple small peripheral tears. 
(3) Detachments in the senile when only minimal surgical interference can be withstood.

(4) Previously failed scleral resections, drainage, and diathermy procedures.

The operation can easily be repeated if necessary, and it causes relatively little disturbance to the eye and surrounding tissues.

Between June, 1959, and March 30, 1961, Arruga performed 169 operations, of which 123 resulted in cures and 46 failed (Arruga, 1958, 1960, 1961, 1962; Boyd, 1958). Since then, over 200 successful operations had been recorded when the author visited Arruga's clinic in June, 1963.

The most important decision in this operation is the assessment of the tightness of the Supramid or 000 Nylon suture. If it is tied too tightly, as in some early cases, the string cuts through to the retina like a "cheese-wire", and may appear in the vitreous. However, such a result need not be regarded with undue anxiety, for the sclera has usually healed behind it and the ocular tension remains normal.

An eye in which the string is too tight will usually be red, painful, and irritable during the post-operative period. In these cases the Supramid should be loosened or removed. Eyes which develop the "string syndrome", in which the string is seen under the retina, may well remain quiet and the retina flat.

\section{(4) Liquid Silicone in Retinal Surgery}

Stone (1958) reported on the experimental injection of liquid silicone into the vitreous cavity of rabbits. He found it remarkably well tolerated over a period of 2 years, post-cortical cataract and glaucoma being the principal complications.

The first clinical report of the use of liquid silicone was published by Cibis, Becker, Okun, and Canaan (1962). The rabbit experiments had been confirmed, and 33 patients considered to be "hopeless" surgical cases were selected.

(i) Giant Tears with a Retroflexed Retina.-This group forms 1 per cent. of all retinal detachments, and as yet there is no surgical treatment offering a reasonable hope of success. This group showed encouraging results over a period of 7 months. In four of the five eyes it was a primary procedure, combined with conventional buckling and diathermy. In three eyes the retina was re-attached; in the fourth it was initially replaced, but later detached again elsewhere; in the fifth, it failed.

(ii) Detachments with Massive Vitreous Retraction.-In this group the results were not so encouraging. Cibis (personal communication) states that it is possible to peel off preretinal organized fibrous tissue by injecting silicone directly over the optic disc. As the globule increases, the retina is pushed flat, and the fibrous membrane advances to the equator. The sub-retinal fluid being drained, this membrane is then cut and silicone injected in front of it to prevent further traction on the retina. It is important to preserve an intact vitreous face where possible, and prevent silicone entering the anterior chamber.

(iii) Advanced Retinal Atrophy and Multiple Tears.-This group was less successful but in all nearly 50 per cent. of these desperate cases were improved.

Such a complicated technique should be learnt at first-hand, but eventually it may prove possible to use silicone material in preference to intravitreal air or saline. 


\section{Summary}

The history of the role of plastics in retinal surgery is briefly outlined. The indications for and results of these procedures are still being assessed, and appraisal is made more difficult by the absence of international standards of success in this field. New materials are rapidly evolving before long-term results of earlier methods are forthcoming.

As a result of these developments, the only type of primary retinal detachment which remains virtually incurable is that due to giant disinsertion of half the globe with a rolled-over retina.

I wish to acknowledge the training and assistance I have received from Mr. C. Dee Shapland, Mr. L. G. Fison, and Mr. J. R. Hudson.

\section{REFERENCES}

AMSLER, M. (1956). Ophthalmologica (Basel), 131, 324.

Arruga, A. (1960). Maroc méd., 39, 345.

Arruga, H. (1952). Amer. J. Ophthal., 35, 1573. (1957). Mod. Probl. Ophthal. (Basel), 1, 443. (1958a). Arch. Soc. oftal. hisp.-amer., 18, 55. (1958b). Bull. Soc. franc. Ophtal., 71, 571. (1961). Ber. dtsch. ophthal. Ges., 64, 480. (1962). Arch. Soc. oftal. hisp.-amer., 22, 813.

Boyd, B. F. (1958). Highlights of Ophthalmology, pt. 2, p. 170.

Brockhurst, R. J., Schepens, C. L., and OkamurA, I. D. (1958). A.M.A. Arch. Ophthal., $60,1003$.

Cibis, P. A., BeCKer, B., Okun, E., and CanaAn, S. (1962). Ibid., 68, 590.

Custodis, E. (1951). Ber. dtsch. ophthal. Ges., 57, 227. (1953). Ibid., 58, 102.

(1956). Klin. Mbl. Augenheilk., 129, 476.

(1959). Ber. dtsch. ophthal. Ges., 62, 202.

- (1962). Bull. ophthal. Soc. Egypt, 55, 73.

Everett, W. G., and Sharrer, M. C. (1961). Trans. Amer. Acad. Ophthal. Otolaryng., 65, 197.

GirARD, L. J., and McPHERSON, A. R. (1961). Bull. Soc. franç. Ophtal., 74, 190.

(1962). Arch. Ophthal. (Chicago), 67, 409.

GonIN, J. (1929). Ber. dtsch. ophthal. Ges., 47, 46, 445. (1930a). Arch. Ophthal. (Chicago), 4, 621. (1930b). Trans. ophthal. Soc. U.K., 50, 531.

Jess, A. (1937). Brit. J. Ophthal., 17, 726.

LinCOFf, H. (1960). A.M.A. Arch. Ophthal., 64, 201.

LINDNER, K. (1933). Z. Augenheilk., 81, 277.

McGregOR, R. R. (1954). "Silicones and Their Uses". McGraw-Hill, New York. (1957). "Silicones in Medicine and Surgery". McGraw-Hill, New York.

MeYer-SCHWICKerath, G. (1954). "Proc. XVII Int. Congr. Ophthal., Sept., 1954. Montreal-New York". (1960). "Light Coagulation", trans. S. M. Drance. Mosby, St. Louis; Kimpton, London.

PAU, H. (1959a). Amer. J. Ophthal., 47, 565.

(1959b). Ophthalmologica (Basel), 138, 12.

Okamura, I. D., and SchePens, C. L. (1955). Sight Sav. Rev., 25, 138.

-, , and Brockhurst, R. J. (1959). A.M.A. Arch. Ophthal., 62, 445.

Regan, C. D. J., SchePens, C. L., OKamura, I. D., BrockhuRST, R. J., and MCMefl (1962). Ibid., $68,313$. RosengRen, B., and TörnQuist, R. (1958). Acta ophthal. (Kbh.), 36, 426.

SCHEPENS, C. L. (1951). A.M.A. Arch. Ophthal., 45, 1. , ed. (1960). "The Importance of the Vitreous Body in Retina Surgery", Mosby, St. Louis; Kimpton, London.

—, Okamura, I. D., and Brockhurst, R. J. (1957). A.M.A. Arch. Ophthal., 58, 797.

,,,-- (1958). Ibid., 60, 84.

St, and Regan, C. D. J. (1960). Ibid., 64, 868.

Shapland, C. Dee (1951a). Proc. roy. Soc. Med., 44, 420. (1951b). Trans. ophthal. Soc. U.K., 71, 29. (1955). Ibid., 75, 405. (1957). Ibid., 77, 69. (1960a). Ibid., 80, 677. (1960b). In "British Surgical Practice: Surgical Progress, 1960", p. 316. Butterworths, London.

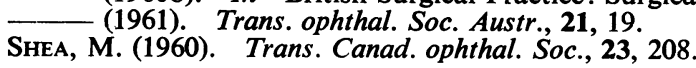


Stone, W., Jr. (1958). New Engl. J. Med., 258, 486.

Strampelli, B. (1954). Ann. Ottal., 80, 275. (Zbl. ges. Ophthal., 1955, 64, 176).

VANNAS, M. (1958). Acta ophthal. (Kbh.), 36, 432.

\section{ADDITIONAL BIBLIOGRAPHY}

Adams, S. (1957). Trans. Canad. ophthal. Soc., 9, 185.

AsbuRY, T., and Vaughan, D. G. (1956). Amer.J. Ophthal., 42, 36.

BarraQuer Moner, J., and Muiños Simon, A. (1956). Ibid., 41, 92.

BARREAU, K. R. (1960). Arch. chil. Oftal., 17, 91.

BLACK, G. W. (1957). Trans. ophthal. Soc. U.K., 77, 89.

BoniuK, M., and Zimmerman, L. E. (1961). Trans. Amer. Acad. Ophthal. Otolarying., 65, 671.

Chamlin, M., and RuBNer, K. (1956). Amer. J. Ophthal., 41, 633.

ChenTSOVA, Y. (1958). Vestn. Oftal., No. 6, 35.

Clark, G. (1962). Trans. Amer. Acad. Ophthal. Otolarying., 65, 671.

COLYEAR, B. (1960-1). Highlights of Ophthalmology, 4, 55.

Dellaporta, A. (1951). Klin. Mbl. Augenheilk., 119, 135.

(1954). A.M.A. Arch. Ophthal., 51, 525.

(1954). Amer. J. Ophthal., 42, 189.

(1962). Ibid., 54, 951.

DerivauX, J. H. (1962). Sth. med. J. (Bgham. Ala.), 55, 1027.

DetTINGER, G. B., and BoWERS, W. F. (1957). Surgery, 42, 325.

Diaz-Domínguez, D. (1962). Hisp. méd., 19, 29.

El-MASRI, A. (1962). Bull. ophthal. Soc. Egypt, 55, 97.

EL-ZENEINY, I. H. (1961). Ibid., 54, 273.

EVERETT, W. G. (1955). A.M.A. Arch. Ophthal., 53, 865. (1956). Ibid., 56, 34.

Scotr, D. C., and Sharrer, M. C. (1962). Trans. Amer. Acad. Ophthal. Otolarying., 66, 614.

Fison, L. (1955). Trans. ophthal. Soc. U.K., 75, 43. (1956). Ibid., 76, 259.

GIRARD, L. J. (1959). Med-Southern Section, Houston, Texas. (1960). Highlights of Ophthalmology, 4, 55.

Hamilton, R. S. (1962). Surv. Ophthal., 7, 249.

Harrison, J. W., Swanson, D. S., and Lincoln, A. F. (1957). Arch. Surg., 74, 139.

HAVENER, W. H., and Olson, R. S. (1962). Arch. Ophthal. (Chicago), 67, 721.

HeFNY, W. (1959). Bull. ophthal. Soc. Egypt., 53, 49.

Hrrz, J. B. (1957). Trans. Amer. ophthal. Soc., 55, 477.

HöPPING, W. (1961). Ber. dtsch. ophthal. Ges., 64, 512.

JonKers, G. H. (1961). Klin. Mbl. Augenheilk., 138, 790.

Kazdan, M. S., Henderson, J. W., and Parkhill, E. D. (1959). Amer. J. Ophthal., 47, No. 1, pt 2, 437.

KeLLY, T. S. B. (1960). Trans. ophthal. Soc. U.K., 80, 619.

Kennaway, A. (1958). In "Modern Trends in Surgical Materials", ed. L. Gillis. Butterworths, London.

KLEMENS, F. (1960). Klin. Mbl. Augenheilk., 137, 222.

LASKy, M. A., and Blumenthal, G. (1959). Amer. J. Ophthal., 48, 199.

LEWIS, E. L. (1959). Ibid., 48, 258.

LINNEN, H. J. (1959). Ber. dtsch. ophthal. Ges., 62, 209.

Lister, A., Phimps, A. S., and Shapland, C. Dee (1951). Proc. roy. Soc. Med., 44, 413.

MCDONALD, P. R. (1960). Amer. J. Ophthal., 50, 1247. , ANNESLeY, W. H., RifE, C. F., and SARIN, L. K. (1963). I Ibid., 55, 52.

MAeder, G. (1957). Mod. Probl. Ophthal. (Basel), 1, 455. (1956). Ophthalmologica (Basel), 131, 327.

MALBRÁN, E. (1961). Trans. ophthal. Soc. U.K., 81, 539. and DodDs, R. (1961). Klin. Mbl. Augenheilk., 138, 465.

MALBRÁN, J., and MALBRÁN, E. (1959). Brit. J. Ophthal., 43, 288.

MorTimer, C. B., and MACraE, H. M. (1960). Trans. Canad. ophthal. Soc., 23, 184.

MOURGUE, G. (1960). Klin. Mbl. Augenheilk., 136, 598.

Narat, J. K., Cangelosi, J. P., and Belmonte, J. V. (1957). Surg. Forum., 7, 176.

OKUN, E. (1961). Amer. J. Ophthal., 51, 369.

PARRY, R. (1956). Trans. ophthal. Soc. U.K., 76, 443.

PAUfIQUE, L. (1959). Trans. ophthal. Soc. U.K. (Bowman Lecture), 79, 22. and Hervouet, F. (1962). Ann. Oculist. (Paris), 195, 385.

Picó, G. (1958). Amer. J. Ophthal., 45, 227.

POSNER, A. (1953). Eye, Ear, Nose, Throat Monthly, 32, 656.

RomaINe, H. H. (1961). Trans. Amer. Acad. Ophthal. Otolaryng., 65, 718.

SHAFER, D. M. (1956). N.Y. St.J. Med., 56, 3300. (1956). Highlights of Ophthalmology, 1, 3 . (1957). Trans. Amer. Acad. Ophthal. Otolaryng, 61, 194. (1958). N.Y. St. J. Med., 58, 2503.

Shevalev, V. E. (1962). Oftal. Zh., 2, No. 2, p. 67 (Abstr. in Ophthal. Lit. (Lond.), 16, 75).

Stenstrom, W. J. (1961). Med. biol. Ill., 11, 157. 
Stout, A. P. (1952). Proc. Soc. exp. Biol (N.Y.), 79.

SUDARSKY, R. D., and KATZIN, H. (1959). A.M.A. Arch. Ophthal., 62, 503.

Topalis, C. (1961). Bull. Soc. hellén. Ophtal., 29, 115.

Valenzuela, R. (1960). Arch. chil. Oftal., 17, 84.

VALENZUELA ENCINA, R. (1962). Ophthal. ibero.-amer., 23, 34.

WeVE, H. (1953). Trans. ophthal. Soc. Aust., 13, 101.

WIRTH, A. (1958). Aggiorn. Ter. oftal., 10, Suppl. 